International Journal of Biological Sciences

ISSN 1449-2288 www.biolsci.org 2006 2(3):149-160

Review

C2006 Ivyspring International Publisher. All rights reserved

\title{
A gene catalogue of the amphioxus nervous system
}

\author{
Èlia Benito-Gutiérrez
}

Departament de Genètica Facultat de Biologia, Universitat de Barcelona, Spain.

Corresponding address: Èlia Benito-Gutiérrez, Avinguda Diagonal 645, Barcelona. E-08028. Spain. Tel: +34 934021500; Fax: +34 934024420; e-mail: eliabenito@ub.edu

Received: 2006.02.14; Accepted: 2006.05.21; Published: 2006.05.22

The elaboration of extremely complex nervous systems is a major success of evolution. However, at the dawn of the post-genomic era, few data have helped yet to unravel how a nervous system develops and evolves to complexity. On the evolutionary road to vertebrates, amphioxus occupies a key position to tackle this exciting issue. Its "simple" nervous system basically consists of a dorsal nerve cord and a diffuse net of peripheral neurons, which contrasts greatly with the complexity of vertebrate nervous systems. Notwithstanding, increasing data on gene expression has faced up this simplicity by revealing a mounting level of cryptic complexity, with unexpected levels of neuronal diversity, organisation and regionalisation of the central and peripheral nervous systems. Furthermore, recent gene expression data also point to the high neurogenic potential of the epidermis of amphioxus, suggestive of a skin-brain track for the evolution of the vertebrate nervous system. Here I attempt to catalogue and synthesise current gene expression data in the amphioxus nervous system. From this global point of view, I suggest scenarios for the evolutionary origin of complex features in the vertebrate nervous system, with special emphasis on the evolutionary origin of placodes and neural crest, and postulate a pre-patterned migratory pathway of cells, which, in the epidermis, may represent an intermediate state towards the deployment of one of the most striking innovative features of vertebrates: the neural crest and its derivatives.

Keywords: Non-neural ectoderm, neurogenic potential, cryptic complexity, neural crest, placodes.

\section{Introduction}

The evolution of the nervous system in the Animal Kingdom is currently under major debate in Evolutionary Developmental Biology and Comparative Embryology [1]. In this context, the evolutionary path that leads to the morphological complexity of the nervous system passes through the invertebrate/vertebrate transition. At the beginning of the $X X^{\text {th }}$ century, the cephalochordate amphioxus occupied the most prominent role in illuminating, at the morphological level, such a transition (see [2] for an historical perspective). During the last decade, increasing information on the molecular aspects of amphioxus development has revealed a number of previously hidden features. One prominent example is the molecular regionalisation of the amphioxus nervous system, which is greatly hindered by its anatomical simplicity. The central nervous system of an adult amphioxus is a mere tubular nerve cord lying dorsally over the notochord. The nerve cord and the notochord cover together the entire length of the animal, except in the anterior region, where only the notochord reaches the rostral tip of the body (Fig. 1). This exclusive rostral expansion of the notochord is a hallmark of the taxon Cephalochordata (corda - for corda dorsalis, original name of the notochord - in the head). The only externally visible landmarks of the amphioxus nerve cord are discrete enlargements at both the anterior and posterior ends, regarded as the anterior vesicle and the caudal ampulla, respectively. Transiently during embryonic development, in young larvae, the anterior swelling is commonly known as cerebral vesicle and is much more pronounced than in adults. Apart from the serially repeated exit points of the dorsal nerves, the nerve cord of amphioxus is devoid of rhombomeres or other external morphological indications of segmentation. The outgoing dorsal nerves, unsupplied with ganglia, contribute to the peripheral nervous system by innervating most of the organs of the body, shaping an irregular nerve net, where a number of peripheral neurons are also accommodated [3] In contrast with the anatomically non-regionalised central nervous system and the apparently disorganised peripheral nervous system, the discrete expression patterns of distinct genes and the specific distribution of certain proteins outline a completely different chronicle for the nervous system of amphioxus. Most of the neural genes characterised to date reveal gapped expression domains within the developing central nervous system, and restricted expression to certain cell subpopulations within the embryonic epidermis. Retinoic acid treatments greatly affect these gene expression domains [4], suggesting a well-controlled pre-patterning that defines distinct territories, not only within the neural ectoderm but also within the epidermis of amphioxus embryos.

After two centuries of heated debate, amphioxus is still an epicentre for the controversial evolutionary 
origins of vertebrates. Whatever its actual position, as the sister group of vertebrates, as the earliest chordate, or as (less likely) the earliest deuterostome [5], its privileged phylogenetic position sets amphioxus in the appropriate place to cast light on some of the main transitions that occurred during animal evolution: the origin of deuterostomes, the origin of Chordates, or the origin of vertebrates, all of them correlated with novel evolutionary features, and some of them linked to the elaboration of the most complex nervous systems. The relative phylogenetic position of cephalochordates and urochordates has very recently received a lot of attention [6]. Both cephalochordates and urochordates are invertebrate chordates that share with vertebrates certain anatomical features: a notochord, pharyngeal slits and a dorsal hollow nerve cord. However, these pre-vertebrate characteristics are lost in tunicates after metamorphosis, while they are maintained for life in cephalochordates. Furthermore, cephalochordates but not urochordates possess additional vertebrate-like characters, such as a postanal tail and segmentally arranged muscles (myomeres) (Fig. 1). Both clades include the only invertebrates able to form a dorsal nerve cord through neurulation. However, unlike in urochordates, in amphioxus the nervous system seems to be developmentally active beyond metamorphosis. This is supported by modern anatomy [3], which shows that cytoarchytectural reorganisations should occur within the nerve cord of amphioxus until reaching a definitive internal structure in the adult.

The present communion between modern morphology and the use of molecular biology tools is revealing an unexpected variety of cell types, territories and boundaries along the antero-posterior axis of the nerve cord and on the epidermis of amphioxus. Here I attempt to summarize distinct patterns of gene expression, giving an overall view of the formation of the central and peripheral nervous systems of amphioxus and suggesting the possible origin of two characteristic neural features in vertebrates: the placodes and the neural crest. consequence of the animal-vegetal polarity of the oocyte, induced by the sperm entry point during fertilisation. At the onset of gastrulation, the vegetal pole of the blastula invaginates, leaving a wide-open blastopore, which subsequently closes. As soon as invagination begins, AmphiWnt1 turns on around the blastoporal opening in conjunction with $A m B r a$, followed by the expression of AmphiWnt8 and a down-regulation of $\beta$-catenin in the invaginating mesendoderm $[7,8]$. This territorial area homing the expression of these genes is soon segregated into the blastoporal lips, which remain on the posterior side of the embryo and will contribute to the tail bud later in development [9].

Other amphioxus Wnt genes are also expressed around the blastopore in an overlapping pattern to that of AmphiNotch and AmBra [7, 10, 11]. This indicates that both the Wnt and Notch pathways may act as a posterior signalling centre involved in the specification and maintenance of the posterior identity. Whether the Notch and Wnt signalling systems are involved in the specification of the dorso-ventral axis remains unclear. However, it has been suggested that Wnt signals may be involved in restricting expression of genes such as AmphiSox1/2/3, AmphiDRAL and AmphiDll to the ectoderm [7]. AmphiSox1/2/3 and AmphiNeurogenin are the earliest known markers for the presumptive neuroectoderm in amphioxus [12]. The expression of both largely overlaps at the early gastrula, on the outer dorsal epiblast (ectoderm), thus indicating the existence of a dorso-ventral axis already at this stage. Opposite AmphiSox1/2/3 and AmphiNeurogenin, AmphiDRAL is expressed in the non-neural ectoderm, suggesting that the neural/nonneural boundary might become delimited early in development [13]. Throughout gastrulation, some of the genes involved in neural patterning are expressed in the dorsal blastoporal lip, which has been regarded as the homolog of the amphibian Spemann's organiser [14], crucially involved in neural induction. In vertebrates, the early nodal expression is involved in the establishment of the Spemann's organiser and

\section{Figure 1. \\ Morphological \\ features of an adult amphioxus. Lateral view showing the internal anatomy and part of the overlying segmented muscle blocks (myomeres).}

\section{Early gene expression}

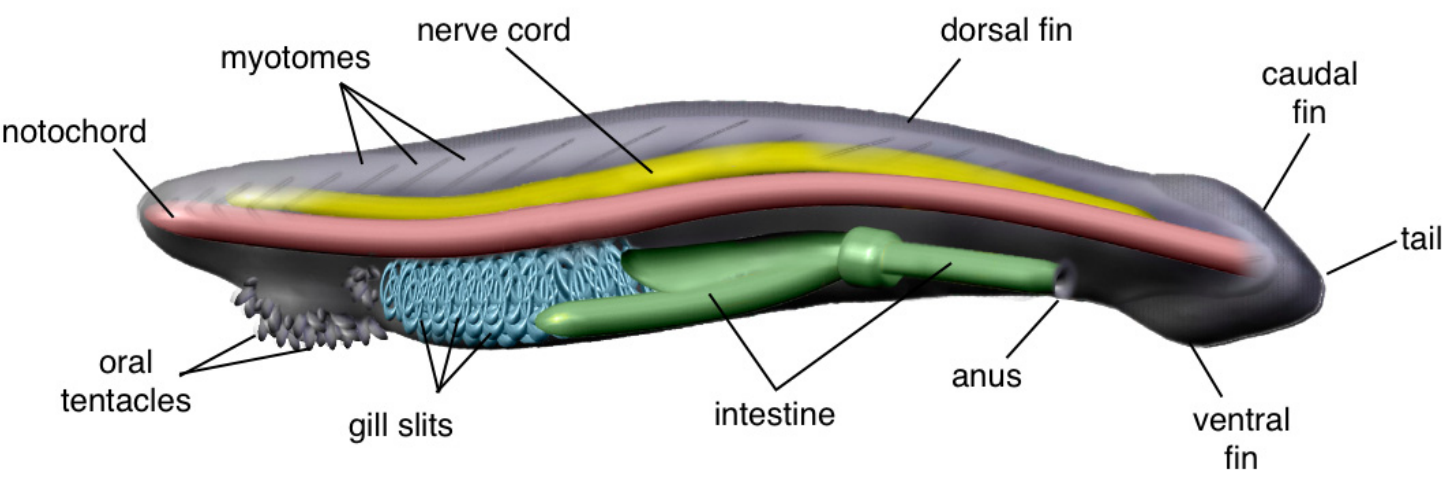

In

amphioxus, the embryonic anterior-posterior axis is determined early (by the time of gastrulation), as a induces the expression of organiser-specific genes such as goosecoid. In amphioxus, AmphiNodal's 
strongest expression is in the inner hypoblast (mesendoderm) of the dorsal blastoporal lip [15]. Therefore, AmphiNodal might well induce the expression of goosecoid in the dorsal blastoporal lip, where it overlaps with other organiser-related genes such as AmHNF3, AmBra and AmphiFoxD, but not AmphiOtx [11, 16-19]. This incomplete overlapping expression occurs for a short period of time and, in comparison with vertebrates, it is slightly delayed in development. Thus, it is unclear to what extent the dorsal blastoporal lip functions, if it does, as a dorsalventral organiser, though it may have some properties related to the Spemann's organiser, such as influencing the formation of the neural plate and the underlying chordamesoderm.

As gastrulation proceeds, some genes begin to be restrictively expressed in certain regions of the neuroectoderm, which may be an anticipation of the cryptic regionalisation of the neural tube and the epidermis observed in succeeding stages. Islet and AmphiPax6 are first solely expressed in the anterior neuroectoderm, whereas AmphiEvxA is expressed just in the posterior neuroectoderm and AmphiMsx in the middle part [20-23]. The homogeneous expression of AmphiSox $1 / 2 / 3$ and AmphiNeurogenin in the dorsal epiblast is gradually restricted only to the neural ectoderm [12]. AmphiZic and AmphiVent, which were earlier widely expressed dorsally, become restricted to the lateral regions of the nascent neural plate [14, 24].

Conversely, other genes are expanded to the neuroectoderm, as shown by AmphiBrn1/2/4, AmphiPax3/7 and the various AmphiHairy genes. As the gastrula elongates to reach the earliest neurula stage, the expression of AmphiBrn1/2/4, initially located in the dorsal epiblast, gradually spans from the posterior to the anterior neural plate [25]. The initial expression of AmphiPax3/7 in the dorsal presumptive axial and paraxial mesoderm is additionally extended to the dorsal ectoderm, where it also appears at the lateral edges of the presumptive neural plate [26]. Likewise, the AmphiHairy genes also label the forming neural plate, in this case accompanied by a complementary striped expression in the presumptive somitic mesoderm [27]. This raises the recurrent question on the effect that mesoderm segmentation might exert on the molecular regionalisation of the neural tube in amphioxus. Although not segmental, the mesodermal expression of Id and AmphiDmbx could be tentatively related to this issue, since in vertebrates they have a welldefined location within the developing central nervous system [28, 29]. Furthermore, the apposed ectodermal-mesodermal expression also observed for the amphioxus snail gene, which is detected in the dorsal presumptive somitic mesoderm and the overlying edges of the forming neural plate, and several other genes (e.g. AmphiZic, AmphiVent) also suggest a collaborative role between the two germ layers [30].

\section{Patterning of the neural tube}

At the end of gastrulation, as the neural plate starts to form, the amphioxus embryo becomes more vertebrate-like. However, in contrast with vertebrates, neural folds do not form during amphioxus neurulation. Instead, the non-neural ectoderm detaches from the edges of the open neural plate, overgrowing laterally over the neural plate and fusing in the dorsal midline. As the non-neural ectoderm covers the neural plate, the lateral edges of the latter curl up dorsally and fuse in the dorsal midline, underneath the non-neural ectoderm, to form the neural tube. Once the neural tube is formed, it stills remains anteriorly open through the neuropore. Subsequently, as the neurula elongates, the posterior neural tube and the adjacent notochord and somites stem from the tail bud, which probably still maintains some of the organiser properties mentioned above. Throughout neurulation, the various gene expression patterns are highly dynamic within the central nervous system (Table 1) and reveal discrete molecular boundaries, most of them hidden at a morphological level.

The central nervous system of amphioxus neurulae, in its advanced stages, consists of a dorsal neural cord lacking constrictions along its rostrocaudal axis. The only regional difference lies at the anterior end, only regional difference lies at the anterior end only regional difference lies at the anterior end where the neural canal is slightly dilated into a cerebral vesicle, anterior to the level of somite 1 and up to the anterior part of somite 2. Most of the cerebral vesicle is dominated by the expression of AmphiOtx, yet with a gap of expression halfway along its anterior-posterior axis. The anterior domain of AmphiOtx covers a region that includes the infundibular organ. This organ is the source of the Reissner's fiber, which fills the central neural canal, and is probably the homologue of the subcommisural organ of the vertebrate diencephalon [16]. In this region, AmphiBF-1 labels a subset of AmphiOtxpositive cells [31]. Similarly, AmphiDll-positive cells are also embedded in the rostral domain of AmphiOtx, but located more anteriorly than AmphiBF-1, in the preneuroporal region [32]. AmphiD1 is also expressed in the cerebral vesicle at the level of the presumptive infundibular organ, while AmphiTH is expressed at the level of the presumptive lamellar organ, which in turn is covered by the caudal expression of AmphiOtx $[33,34]$. These sharp expressions probably reflect a complex internal morphology within the cerebral vesicle; this is also observed for AmphiPax6, which is expressed in a few cells of the developing frontal eye [20]. The posterior expression of AmphiOtx overlaps with that of AmphiDll, AmphiPax6, AmphiSim and the anteriormost expression of AmphiFoxB. The delimited expression of AmphiSim in this area is especially interesting, since it is a marker of the posterior diencephalon and midbrain in vertebrates. However, amphioxus orthologues of other vertebrate midbrain and MHB (Midbrain-Hindbrain Boundary) markers, 
such as AmphiEvx, AmphiEn, AmphiPax2/5/8 and AmphiWnt1, have failed to provide evidence for a true midbrain and MHB homolog in amphioxus [29,35]. Both AmphiBf-1 and AmphiDll are orthologue genes to those marking the vertebrate telencephalon and, in the case of AmphiDll, other parts of the vertebrate diencephalon as well. Together with the expression of AmphiOtx, the orthologues of which are markers of the vertebrate telencephalon, diencephalon and midbrain, and the territorial domain occupied by AmphiSim, combined gene expression suggests that the amphioxus cerebral vesicle is largely homologous to the vertebrate forebrain (telencephalon plus diencephalon), although certain homology with the midbrain cannot be completely ruled out.

In the hypothetical absence of a midbrain homolog in amphioxus, the territory posterior to the cerebral vesicle, caudal to AmphiOtx expression at the level of somite 2 , has been widely seen as a homolog of the craniate hindbrain. Following the expression of AmphiOtx, amphioxus hindbrain is subjugated to the expression of different Hox genes, partially overlapped along the anterior-posterior axis. Spatially, the first Hox gene expressed in the anterior hindbrain is AmphiHox1 (somites 2-4), followed by AmphiHox3 (somites 4-8) and AmphiHox4 (somites 6-8) [36]. AmphiFoxB is expressed segmentally as well, concomitantly with Hox genes, though it shows a prominent gap of expression at the level of somite 5, where the pigment spot will form and, intriguingly, where the expression of other segmental genes is also disrupted (e.g. Mnx, Islet) [35].

Other genes broadly expressed within the neural tube of amphioxus are: AmphiSox1/2/3, AmphiNetrin, AmphiF-spondin, the different Hairy genes and AmphiBrn1/2/4. All of them label certain fractions of the hindbrain and some of them include some spots of expression within the cerebral vesicle. While AmphiSox $1 / 2 / 3$ is excluded along the midline and the anterior part of the neural tube, AmphiNetrin shows a fairly complementary pattern, being expressed just along the midline [12,37]. Notwithstanding, AmphiNetrin expression in the floor plate lasts longer than AmphiSox $1 / 2 / 3$ expression does and always overlies its own expression in the dorsal notochord, even below the cerebral vesicle (from which it is excluded), until the larval stages, when AmphiNetrin is lost at both anterior and posterior ends of the notochord. The long-lasting expression of AmphiNetrin in the floor plate suggests a role of the amphioxus floor plate in the control of axon path finding, possibly guiding newborn neurons within the nerve cord [37]. AmphiF-spondin expression by the end of neurulation largely overlaps the expression of AmphiNetrin, though covering broader areas within the neural tube, including the cerebral vesicle, where it shows a gap of expression just on the ventral side [38]. Similar to AmphiSox1/2/3, AmphiBrn1/2/4 is excluded from the midline, but is additionally expressed in the cerebral vesicle with the same gap of expression as the one observed for the AmphiF-spondin gene [25].
Throughout the neural tube, amphioxus Hairy genes are expressed in complementary patterns. AmphiHairyB is expressed in the anterior neural tube, spatially followed by AmphiHairyC and AmphiHairyD, being AmphiHairyA the most restricted one to the posterior neural tube. Independently, all of them show gapped expression and overlap at certain levels, just in some cases filling the gaps of one another. As mentioned previously, in general the expression of the different AmphiHairy genes in the neural tube is accompanied by a striped expression in the somitic mesoderm, but in the case of AmphiHairyC and AmphiHairyD, it is further escorted by their expression in the notochord [27]. The apposed expression of the notochord and the neural plate is also observable for AmphiNetrin, AmHNF3 and AmphiHh, at neurula stages $[17,37,39]$. Though the expression of these three genes is undetectable in the ventral cerebral vesicle, it is clearly seen throughout the rest of the neural tube and along the whole length of the notochord, including the portion underlying the cerebral vesicle. In vertebrates, the notochord is a transient embryonic structure that acts as an organiser inducing the floor plate and cooperating in the establishment of the dorso-ventral axis of the neural tube and somites. Although in amphioxus this structure is permanent, based on comparable gene expression patterns, it may well have properties similar to those of the vertebrate notochord, yet with a longer period of action that could extend beyond metamorphosis. In this regard, however, the role of the anterior notochord is obscured by the fact that genes such as AmphiNetrin, AmHNF3 or AmphiHh seem to be unable to induce floor plate fates in the ventral cerebral vesicle, which suggests that the cells lying ventrally in the cerebral vesicle may not be competent to respond to their signals [37].

\section{Iterative gene expression patterns}

The cryptic internal segmentation of the amphioxus neural tube has been visualized by iterative gene expression patterns. As illustrative examples, AmphiKrox, shox, islet and AmphiMnx share a one somite-wide periodicity of expression throughout the neural tube. All of them are expressed in the Hox-delineated hindbrain regions, though not all their patterns are in the same phase, indicating that different sets of cells take part in the iteration. Both shox and islet transcripts are located at the level of somite boundaries, while AmphiKrox transcripts are centralised at the level of somites and AmphiMnx ones are close to the posterior border of the somites [39-41]. The repetitive pattern appears more synchronised adjacent to the first four somites and is altered at the level of somite number 5 , as occurs with the segmental expression of AmphiFoxB.

Similarly, AmphiCoe and AmphiElav are also iteratively expressed along the nerve cord during neurulation [42-44]. The AmphiCoe-expressing cells within the nerve cord show a periodicity matching the adjacent somites, in a pattern similar to those of AmphiFoxB and AmphiNeurogenin, at the same 
developmental stages [12,35]. Unlike AmphiKrox, shox and AmphiMnx expression, the AmphiCoe transcripts are not solely confined to the ventral part of the nerve cord, since they are also present in dorsal cells lying in comparable positions to those expressing islet. Interestingly, the dorsal expression of both islet and AmphiCoe only occurs beyond the level of somite 5, where the dorsal cells expressing them are displaced anteriorly to the accompanying expressing cells in the ventrolateral floor of the nerve cord [41]. AmphiElav expression throughout neurulation is concomitant with that of the abovementioned iteratively expressed genes. However, though serially arranged, AmphiElavexpressing cells do not clearly match somite boundaries and are located on both the dorsal and ventral sides of the nerve cord, at all levels posterior to the cerebral vesicle [44].

In most cases, the iterative expression of these genes is maintained up to the larval stages, being down-regulated, but not completely missing, at about three days post-fertilisation. Similar expression patterns have been described for other genes, such as AmphiNk2-1, AmphiNk2-2, AmphiFringe or AmphiMsx, although their transcripts are not detected in the neural tube that far in development [21, 45-47]. The four genes are segmentally expressed in the neural tube at mid-neurula stages, just after mesoderm segmentation has commenced, but fade away from these locations by the end of neurulation. Again, this transient expression may correlate mesoderm segmentation with the development of internal metameric neural structures. However, other genes, such as AmphiDach and AmphiERR, show an iterative pattern of expression, most obviously at larval stages $[48,49]$. In both cases, the series of positive cells have a caudal limit of expression at the level of somites 5-6. It would seem that the only genes iteratively expressed beyond the level of somite 5 up to the latest stages of development analysed are AmphiCoe, AmphiElav and AmphiNeurogenin, but always excluding the most posterior part of the neural tube $[12,43,44]$. Since these genes are early markers for neuronal fates, this might suggest that posterior neuronal fates are delayed in development until later larval stages, at which their expression has not yet been analysed.

The combinatorial iterative expression of all these genes, at different times and in distinct subsets of cells, suggests that the amphioxus nerve cord is internally organised in a variety of neurons, segmentally arranged in a dorso-ventral and an antero-posterior order, which might affect their relative connectivity and consequently their particular functions. Although it is difficult to correlate the internal morphology of the embryonic and adult nerve cord, the differentiation events associated with the expression of the above-mentioned genes might only reflect the preliminary organisation of the anterior part of the adult nerve cord, which according to Wicht and Lacalli spans up to the level of myomere number 11 [3]. Given that the intermediate and posterior parts of the adult nerve cord show a slightly distinct internal organisation, these regions could be morphogenetically delineated later in development. Similar early genetic programs could be acting at advanced larval stages and even beyond metamorphosis, when the embryo is still posteriorly elongating and dramatic morphological changes occur along the body, including the formation of certain structures that will be subsequently innervated by the descending branches of the dorsal nerves. However, this possibility is still to be explored, since the metamorphic and post-metamorphic larvae of amphioxus have rarely been used for gene expression studies.

\section{Neural expression in the non-neural ectoderm}

In recent years, the epidermis of amphioxus has received particular attention [50], as a number of genes are specifically expressed by distinct epidermal cell populations during amphioxus embryogenesis, which indicates that distinct genetic programmes are switched on in particular cells and territories of epidermal tissue, previously thought to be uniform. Some of these genes, such as AmphiCoe, AmphiElav and AmphiTrk, spread spottily over the epidermal surface of the embryo [43,44,51]. While AmphiCoe and AmphiElav are also expressed in the central nervous system, by the time they do in epidermal cells, AmphiTrk expression is solely confined to the nonneural ectoderm during neurulation, yet is restrictively expressed in the central nervous system in adult amphioxus. Within the neuroectoderm, all three of these genes are expressed in developing neuronal precursors, or putative mature neurons in the case of AmphiTrk. Noticeably, the respective orthologue genes in vertebrates are widely expressed in neuronal precursors during embryogenesis. All AmphiCoe, AmphiElav and AmphiTrk genes are expressed by scattered individual epidermal cells distributed over the ventrolateral flanks of neurulae. These cells show a distinctive elongated morphology that clearly sets them apart from surrounding epidermal cells. This dissimilarity is most obvious as neurulation proceeds. The number of cells expressing AmphiElav is apparently higher than the number of cells expressing AmphiCoe or AmphiTrk, which suggests that the embryonic epidermis might contain sub-populations of neuronal cells, which might depend on the combinatorial or differential expression of certain genes, such as AmphiCoe or AmphiTrk, to abandon their epidermal condition. Thus, the scattered epidermal expression of genes involved in neural specification or differentiation suggests a neurogenic potential for the embryonic epidermis of amphioxus, which would be able to generate neuronal cells from ordinary ectodermal cells, giving rise, among other cells perhaps, to the primary sensory neurons observed by Scanning Electron Microscopy (SEM) in the epidermis of late neurulae [43].

Conversely, other genes show a far more limited axial expression in the epidermis than those mentioned above. In particular, the anterior epidermis appears to concentrate much of the epidermal gene 
expression studied to date: AmphiNeurogenin, AmphiPax6, Islet, AmphiTrk, AmphiMsx, AmphiOtx, AmphiBMP2/4, AmphiWnt11, AmphiFoxQ2 and AmphiTob are all expressed in this region, though in a partially overlapping manner $[12,16,20,21,41,51,52-55]$. This could correlate with the concurrence of a variety of specialised sensory cell types morphologically characterised in the anterior part of late larval and adult amphioxus specimens [3]. In this respect, the rostral expression of AmphiMsx and AmphiTrk at early larval stages has been related to the development of the Corpuscles of de Quatrefages, a multi-cellular organ composed of supporting cells and peripheral neurons that remain enclosed within a subepidermal capsule of connective tissue in the rostrum [21,51]. At least some of the peripheral neurons of the Corpuscles of de Quatrefages are primary neurons that send axonal processes to the central nervous system via the rostral nerves, but they are morphologically different from those primary neurons observed by SEM at late neurula stages. The latter probably represent the early steps of differentiation of the Type-I receptors described in late larval and adult amphioxus. The most common receptor cell types are called Type I and Type II receptors. While Type I receptors are primary sensory neurons, Type II receptors are secondary sensory neurons devoid of axons. Both types of sensory neurons are widely distributed over the entire epidermis but appear densely grouped in the rostrum, buccal cirri and tail [3]. The oral region of late larvae is also rich in other neuronal cell types exclusively located in this area, such as the oral spines and those of the synaptic complex of the oral nerve [56]. Although the origins of all these peripheral neurons are not clear, there is no evidence indicating anything other than a local origin. Therefore, the assorted neural-related gene expression in these areas could be associated with distinct steps of neural commitment and differentiation of concrete ectodermal cells.

The overlapping expression area of both AmphiNeurogenin and AmphiPax6 in the ectoderm has been homologised with the vertebrate olfactory epithelia, which expresses the respective orthologous genes $[12,20]$. The vertebrate Pax-6 gene is the most specific maker of the olfactory epithelia, but is also expressed by the lens placode. $M s x 1$ and $M s x 2$ are also expressed in a few other placodes. Conversely, Sox2, Sox3, Neurogenin1 and Neurogenin2, Delta-1 and MyT-1 (NeuroD) are expressed in most of the vertebrate placodes [57]. Few specific placodal genes have been studied to date in amphioxus. Among these, except for AmphiSox 1/2/3, both AmphiPax6 and AmphiNeurogenin are broadly expressed in the rostral ectoderm of early larvae, where AmphiMsx is also expressed, yet covering a narrower area on each side of the larvae. Since amphioxus is devoid of placodes, it is very tempting to correlate these gene expression data with the presence of a putative rudimentary placode-like region, which could be defined as a relatively broad ectodermal area of the rostrum able to give rise to distinct sensorial organs and neuronal subpopulations, and located only in the anterior part of the embryonic ectoderm.

Apart from the scattered expression of certain neural genes (AmphiTrk, AmphiCoe and AmphiElav), the embryonic epidermis of amphioxus expresses a few other genes almost ubiquitously. This is the case of AmphiEvxB, AmphiDral, AmphiDll and AP-2, which are widely expressed in the non-neural ectoderm throughout neurulation [13,32,58,59]. These unexpected expression patterns make interpretation of the function of these genes in amphioxus embryogenesis very difficult. Furthermore, AmphiEvxB is a highly derived gene, fruit of a specific cephalochordate duplication and a general, cephalochordate-specific role, in epidermal functions has been suggested for this gene [58]. However, the overall epidermal expression of the genes characterised to date in amphioxus might lead to an alternative hypothesis. If the embryonic epidermis of amphioxus is endowed with the neurogenic potential of generating assorted neuronal cell types, AmphiDll and $A P-2$ could participate in the epidermal versus non-epidermal sorting of the different cells in the embryonic skin of amphioxus. Given that both genes are homogeneously expressed in this tissue, the decision between epidermal and neural would not rely on the expression of these genes, but on their expression together with other genes such as AmphiElav or other uncharacterised proneural genes.

\section{Caveats on putative neural crest precursors}

The neural crest is a vertebrate-specific embryonic cell population defined by its origins at the neural plate border, migratory capacity, pluripotency and characteristic gene expression profile. Although the genetic machinery of neural crest appears to be at least partially conserved in both urochordates and cephalochordates [60], there is no compelling evidence, to date, for any invertebrate embryonic cell population that has all the properties of the vertebrate neural crest. Even so, some migratory populations have been described in both urochordate and cephalochordate embryos. In both cases, the migratory cells were identified through DiI cell tracing in vivo. While these cells express HNK-1 and Zic gene markers in the ascidian Ectainascidia turbinata, no gene expression profile could be determined for the migratory cells in amphioxus [51,61]. Nevertheless, as noted in the previous section, amphioxus gene expression data demonstrate that particular epidermal cells have a distinctive gene expression profile, which would match the distinctive behaviour of these cells that migrate in a ventro-dorsal direction during neurulation. Although this is only data correlation, the genetic program of these individually migrating cells is likely to be different from the surrounding epidermal cells lacking these properties.

Recent studies on BrdU incorporation throughout amphioxus development demonstrate that the embryonic epidermis of the neurulae is devoid of cell proliferation [62]. These results, together with the absence of apoptosis at the same stages and in tissue 
[63], indicate that the migrated epidermal cells in late neurulae did not relocate by movements caused by the elimination or addition of nearby cells. The absence of epidermal mitosis is consistent with the ciliation of most cells in the embryonic skin of amphioxus neurula. As mitosis and ciliation seem to be mutually excluding in most eukaryotic cells, proliferation and differentiation also seem to be incompatible [62]. This is consistent with some epidermal cells being able to differentiate during neurulation, when mitosis arrests occur. As in vertebrates, AmphiDRAL may be involved in the cell division shutdown, since its downregulation in the epidermis only happens when proliferation is resumed in this tissue, at advanced larval stages $[13,61]$. Under these circumstances, some cells might be able to activate certain differentiation genetic programs that would lead into the early differentiation of the primary neurons observed at late neurula stages [43]. However, such a spatio-temporal genetic program is currently unknown, though it is possible to establish certain associations between gene expression and epidermal subpopulations.

At present, it seems clear that distinct genetic programs are operating in the embryonic skin, distinguishing individual and possibly migrating cells from the rest of the epidermis. As previously mentioned, the most prominent epidermal subpopulations are those labelled by AmphiCoe, AmphiElav and AmphiTrk expression. These are followed by the much smaller subpopulations expressing islet and AmphiERR, which, unlike those expressing AmphiCoe, AmphiElav and AmphiTrk, appear only in the trunk region [4,49]. As a common denominator, all these genes are involved in the specification of neuronal precursors or in neuronal differentiation, thereby strengthening the local neurogenic potential of the amphioxus embryonic epidermis. In tandem with this, one of the most striking features of AmphiTrk and AmphiElav expression is the dorsalisation of the signal as neurulation proceeds, which follows the same direction at the same stages of development of those migrating individual cells observed by DiI tracing [51]. Furthermore, the detailed position of AmphiTrk- and AmphiElav-positive cells locates them within the epidermis or just beneath it, suggesting that if these cells are migrating they might be doing it either through the epidermis or through the subepidermal plexus. On taking this independent evidence together with the expression of the vertebrate Trk and $\mathrm{Hu}$ /Elav orthologue genes in the neural crest and/or its derivatives, it is very tempting to establish parallelism between these cells and the vertebrate neural crest. Therefore, if these cells (AmphiTrk- and AmphiElavpositive cells) individually detached from the epidermal layer and entered the sub-epidermal plexus, until reaching the definitive (and unknown) location at which they would finally differentiate into particular neuronal types, they would conform some of the properties of vertebrate neural crest cells.
The particular migration of vertebrate neural crest cells is also characterised by the precise definition of their individual routes, which are crucially dependent on an antero-posterior Hox code. Interestingly, nested Hox expression in scattered epidermal cells has been observed in the embryonic epidermis of amphioxus [4] by the time that migration begins and the earliest neural gene expression is already occurring. Furthermore, under retinoic acid treatment the location of those individual epidermal cells that express Hox genes is altered, as is that of the AmphiCoe, islet and AmphiERR-positive cells and, importantly, that of the primary neurons observed at late neurula stages [4]. These results suggest that the embryonic skin of amphioxus is probably prepatterned following an antero-posterior Hox code, which in conjunction with other genes would divide the epidermis into distinct territories with particular gene expression profiles. Under this hypothesis, individual cells would migrate vertically through defined routes, which would molecularly, but not morphologically, be delimited into epidermal meridians (Fig. 2). Another particularity of vertebrate neural crest cells is their pluripotency. As mentioned previously, amphioxus skin possesses a moderate diversity of peripheral sensory neurons, probably born locally from normal epidermal cells through different expression profiles [50]. Collation of all the data set out here suggests that the individually migrating cells in amphioxus epidermis may well match cells with a particular gene expression profile that are responsible for the final differentiation into distinct types of peripheral sensory neurons, though these have much less pluripotency than in vertebrates.

In summary, based on: i) the presence of distinct genetic programs in individual embryonic epidermal cells; ii) the ability to migrate as individual cells; iii) the ability to detach, presumably before migration; iv) correlation with the antero-posterior boundaries of Hox expression domains; and v) the partial pluripotency of these cells, I suggest that amphioxus possesses an embryonic cell population that exhibits most of the properties of vertebrate neural crest cells. Thus, it is tempting to speculate that they might represent an intermediate evolutionary step that ended up in the deployment of vertebrate neural crest cells. The main caveats of this thesis are that these cells do not originate from the edges of the neural tube and that migration has the opposite orientation (ventrodorsal). However these two caveats can be reconciled if, in an evolutionary sense, the amphioxus nerve neural system represents an intermediate state, from a diffuse neural epidermal net all around the body, like that of hemichordates [64], to full concentration on the dorsal side of the body, where the nerve tube cohabits in vertebrates with the embryonic germ of the neural crest and placodes.

Figure 2. Hypothetical model for neural crest-like cell migration in amphioxus. The expression of characteristic neural genes in scattered individual cells in the epidermis indicates that neuronal precursors are generated from the 
normal epidermal cells following a particular genetic program switched on during neurulation. These unknown genetic programs should endow these particular cells with additional distinctive properties, which might include the acquisition of individual migratory behaviour. The migration and terminal differentiation of those neuronal precursors, in particular locations, could depend on the prepatterning of the neurula epidermis. This model summarises and gives an oversimplified view of the epidermal expression of different genes that seem to participate in the epidermal patterning of the amphioxus neurula. As in the neural tube, Hox genes are expressed in a nested manner and, together with the expression of AmphiPax6, AmphiEn and $A m p h i C d x$, divide the entire epidermis into meridians of differential expression. All these genes are expressed in a scattered manner, but are delimited along the anteroposterior axis as indicated by colour code. In the case of the Hox genes, the meridians were established by the combinatorial expression of AmphiHox 1, 3, 4 and 6. Under this hypothetical model, those individual cells (red dots) mentioned above, would migrate vertically (arrows) through defined routes, as delimited by each meridian of combinatorial expression.

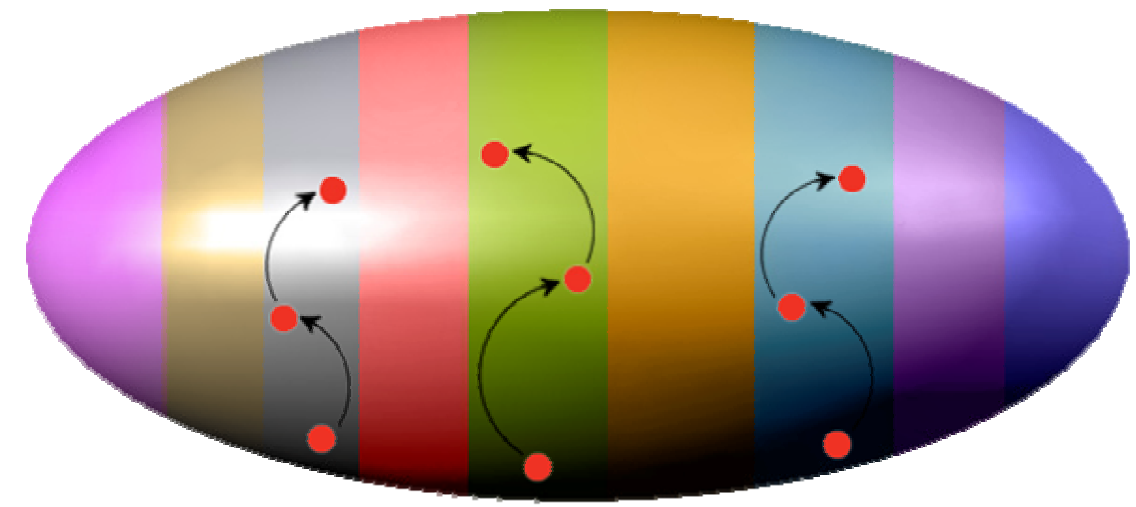

\begin{tabular}{l} 
AmphiPax6 \\
\begin{tabular}{|l|l|l}
\hline AmphiEn & AmphiHox1/3 & AmphiHox3/4/6 \\
AmphIHox1/3/4 & AmphiHox4/6 \\
AmphiHox1 & AmphiHox1/3/4/6 & AmphiCdx \\
Dil labelled migrating cells &
\end{tabular} \\
\hline
\end{tabular}

\section{Conclusion}

Accumulating data on gene expression during amphioxus embryogenesis challenges the "classic" morphological simplicity of the amphioxus nervous system. Segmentally-expressed, iteratively-expressed, "spottily"-expressed genes, neural and non-neural ectodermal specificity, cell migration in the ectoderm and cryptic complexity are all providing us with new insights into the neural genetic programs of this, our old beast, half-way along the path of construction of complex vertebrate nervous systems. In the near postgenomic future, more and more data will be arriving and, hopefully, experimental embryology (by means of genetic manipulation of living embryos) will help clarify the numerous question marks on the evolution of the nervous system, for which the friendly little amphioxus may have some answers.

\section{Acknowledgements}

The author wishes to thank an anonymous referee for very helpful comments and Robin Rycroft for checking the English. The author's research was funded by grant BFU2005-00252 (Spanish Ministry of Education and Science) and by the European Community's Human Potential Programme HPRNCT-2002-00263/BMC 'Neurogenome'.

\section{Conflict of interest}

The author declares that no conflict of interest exists.

\section{References}

1. Holland ND. Early central nervous system evolution: an era of skin brains? Nat Rev Neurosci 2003; 4:617-627.

2. Gans C. Study of lancelets: the first 200 years. Isr J Zool 1996; 42:S3-S11.

3. Wicht $\mathrm{H}$, Lacalli T. The nervous system of amphioxus: structure, development, and evolutionary significance. Can J Zool 2005; 83:122-150.

4. Schubert M, Holland ND, Escriva H, Holland LZ, Laudet V. Retinoic acid influences anteroposterior positioning of epidermal sensory neurons and their gene expression in a developing chordate (amphioxus). Proc Natl Acad Sci U S A 2004; 101:10320-10325.

5. Gee H. Evolution: careful with that amphioxus. Nature 2006; 439:923-924.

6. Delsuc F, Brinkmann $\mathrm{H}$, Chourrout D, Philippe H. Tunicates and not cephalochordates are the closest living relatives of vertebrates. Nature 2006; 439:965-968.

7. Holland LZ. Heads or tails? Amphioxus and the evolution of anterior-posterior patterning in deuterostomes. Dev Biol 2002;

241:209-228

8. Holland LZ, Panfilio KA, Chastain R, Schubert M, Holland ND. Nuclear beta-catenin promotes non-neural ectoderm and posterior cell fates in amphioxus embryos. Dev Dyn 2005; 233:1430-1443.

9. Schubert M, Holland LZ, Stokes MD, Holland ND. Three amphioxus Wnt genes (AmphiWnt3, AmphiWnt5, and AmphiWnt6) associated with the tail bud: the evolution of somitogenesis in chordates. Dev Biol 2001; 240:262-273.

10. Holland LZ, Rached LA, Tamme R, Holland ND, Kortschak D, Inoko H, Shiina T, Burgtorf C, Lardelli M. Characterization and developmental expression of the amphioxus homolog of Notch (AmphiNotch): evolutionary conservation of multiple expression domains in amphioxus and vertebrates. Dev Biol 2001; 232:493-507.

11. Holland PW, Koschorz B, Holland LZ, Herrmann BG. Conservation of Brachyury (T) genes in amphioxus and vertebrates: developmental and evolutionary implications. Development 1995; 121:4283-4291. 
12. Holland LZ, Schubert M, Holland ND, Neuman T. Evolutionary conservation of the presumptive neural plate markers AmphiSox1/2/3 and AmphiNeurogenin in the invertebrate chordate amphioxus. Dev Biol 2000; 226:18-33.

13. Schubert M, Holland ND, Holland LZ. Amphioxus AmphiDRAL encoding a LIM-domain protein: expression in the epidermis but not in the presumptive neuroectoderm. Mech Dev 1998; 76:203-205.

14. Kozmik Z, Holland LZ, Schubert M, Lacalli TC, Kreslova J, Vlcek C, Holland ND. Characterization of Amphioxus AmphiVent, an evolutionarily conserved marker for chordate ventral mesoderm. Genesis 2001; 29:172-179.

15. Yu JK, Holland LZ, Holland ND. An amphioxus nodal gene (AmphiNodal) with early symmetrical expression in the organizer and mesoderm and later asymmetrical expression associated with left-right axis formation. Evol Dev 2002; 4:418425.

16. Williams NA, Holland PW. Old head on young shoulders. Nature 1996; 383:490.

17. Shimeld SM. Characterisation of amphioxus HNF-3 genes: conserved expression in the notochord and floor plate. Dev Biol 1997; 183:74-85.

18. Neidert AH, Panopoulou G, Langeland JA. Amphioxus goosecoid and the evolution of the head organizer and prechordal plate. Evol Dev 2000; 2:303-310.

19. Yu JK, Holland ND, Holland LZ. An amphioxus winged helix/forkhead gene, AmphiFoxD: insights into vertebrate neural crest evolution. Dev Dyn 2002; 225:289-297.

20. Glardon S, Holland LZ, Gehring WJ, Holland ND. Isolation and developmental expression of the amphioxus Pax-6 gene (AmphiPax-6): insights into eye and photoreceptor evolution. Development 1998; 125:2701-2710.

21. Sharman AC, Shimeld SM, Holland PW. An amphioxus Msx gene expressed predominantly in the dorsal neural tube. Dev Genes Evol 1999; 209:260-263.

22. Jackman WR, Langeland JA, Kimmel CB. islet reveals segmentation in the Amphioxus hindbrain homolog. Dev Biol 2000; 220:16-26.

23. Ferrier DE, Minguillon C, Cebrian C, Garcia-Fernandez J. Amphioxus Evx genes: implications for the evolution of the Midbrain-Hindbrain Boundary and the chordate tailbud. Dev Biol 2001; 237:270-281.

24. Gostling NJ, Shimeld SM. Protochordate Zic genes define primitive somite compartments and highlight molecular changes underlying neural crest evolution. Evol Dev 2003; 5:136-144.

25. Candiani S, Castagnola P, Oliveri D, Pestarino M. Cloning and developmental expression of AmphiBrn1/2/4, a POU III gene in amphioxus. Mech Dev 2002; 116:231-234.

26. Holland LZ, Schubert M, Kozmik Z, Holland ND. AmphiPax3/7, an amphioxus paired box gene: insights into chordate myogenesis, neurogenesis, and the possible evolutionary precursor of definitive vertebrate neural crest. Evol Dev 1999; 1:153-165.

27. Minguillon C, Jimenez-Delgado S, Panopoulou G, GarciaFernandez J. The amphioxus Hairy family: differential fate after duplication. Development 2003; 130:5903-5914.

28. Meulemans D, McCauley D, Bronner-Fraser M. Id expression in amphioxus and lamprey highlights the role of gene cooption during neural crest evolution. Dev Biol 2003; 264:430-442.

29. Takahashi T, Holland PW. Amphioxus and ascidian Dmbx homeobox genes give clues to the vertebrate origins of midbrain development. Development 2004; 131:3285-3294.

30. Langeland JA, Tomsa JM, Jackman WRJr, Kimmel CB. An amphioxus snail gene: expression in paraxial mesoderm and neural plate suggests a conserved role in patterning the chordate embryo. Dev Genes Evol 1998; 208:569-577.
31. Toresson H, Martinez-Barbera JP, Bardsley A, Caubit X, Krauss S. Conservation of BF-1 expression in amphioxus and zebrafish suggests evolutionary ancestry of anterior cell types that contribute to the vertebrate telencephalon. Dev Genes Evol 1998; 208:431-439.

32. Holland ND, Panganiban G, Henyey EL, Holland LZ. Sequence and developmental expression of AmphiDll, an amphioxus Distal-less gene transcribed in the ectoderm, epidermis and nervous system: insights into evolution of craniate forebrain and neural crest. Development 1996; 122:2911-2920.

33. Candiani S, Oliveri D, Parodi M, Castagnola P, Pestarino M. AmphiD1/beta, a dopamine D1/beta-adrenergic receptor from the amphioxus Branchiostoma floridae: evolutionary aspects of the catecholaminergic system during development. Dev Genes Evol 2005; 215:631-638.

34. Mazet F, Shimeld SM. The evolution of chordate neural segmentation. Dev Biol 2002; 251:258-270.

35. Wada H, Garcia-Fernandez J, Holland PW. Colinear and segmental expression of amphioxus Hox genes. Dev Biol 1999; 213:131-141.

36. Shimeld S. An amphioxus netrin gene is expressed in midline structures during embryonic and larval development. Dev Genes Evol 2000; 210:337-344

37. Shimeld SM. Characterization of AmphiF-spondin reveals the modular evolution of chordate F-spondin genes. Mol Biol Evol 1998; 15:1218-1223.

38. Shimeld SM. The evolution of the hedgehog gene family in chordates: insights from amphioxus hedgehog. Dev Genes Evol 1999; 209:40-47.

39. Knight RD, Panopoulou GD, Holland PW, Shimeld SM. An amphioxus Krox gene: insights into vertebrate hindbrain evolution. Dev Genes Evol 2000; 210:518-521.

40. Ferrier DE, Brooke NM, Panopoulou G, Holland PW. The Mnx homeobox gene class defined by HB9, MNR2 and amphioxus AmphiMnx. Dev Genes Evol 2001; 211:103-107.

41. Jackman WR, Kimmel CB. Coincident iterated gene expression in the amphioxus neural tube. Evol Dev 2002; 4:366-374.

42. Satoh G, Wang Y, Zhang P, Satoh N. Early development of amphioxus nervous system with special reference to segmental cell organization and putative sensory cell precursors: a study based on the expression of pan-neuronal marker gene $\mathrm{Hu}$ /elav. J Exp Zool 2001; 291:354-364.

43. Mazet F, Masood S, Luke GN, Holland ND, Shimeld SM. Expression of AmphiCoe, an amphioxus COE/EBF gene, in the developing central nervous system and epidermal sensory neurons. Genesis 2004; 38:58-65.

44. Benito-Gutierrez E, Illas M, Comella JX, Garcia-Fernandez J. Outlining the nascent nervous system of Branchiostoma floridae (amphioxus) by the pan-neural marker AmphiElav. Brain Res Bull 2005; 66:518-521.

45. Holland LZ, Venkatesh TV, Gorlin A, Bodmer R, Holland ND. Characterization and developmental expression of AmphiNk2-2, an NK2 class homeobox gene from Amphioxus. (Phylum Chordata; Subphylum Cephalochordata). Dev Genes Evol 1998; 208:100-105.

46. Venkatesh TV, Holland ND, Holland LZ, Su MT, Bodmer R. Sequence and developmental expression of amphioxus AmphiNk2-1: insights into the evolutionary origin of the vertebrate thyroid gland and forebrain. Dev Genes Evol 1999; 209:254-259.

47. Mazet F, Shimeld SM. Characterisation of an amphioxus Fringe gene and the evolution of the vertebrate segmentation clock. Dev Genes Evol 2003; 213:505-509.

48. Candiani S, Kreslova J, Benes V, Oliveri D, Castagnola P, Pestarino M, Kozmik Z. Cloning and developmental expression of amphioxus Dachschund. Gene Expr Patterns 2003; 3:65-69. 
49. Bardet PL, Schubert M, Horard B, Holland LZ, Laudet V, Holland ND, Vanacker JM. Expression of estrogen-receptor related receptors in amphioxus and zebrafish: implications for the evolution of posterior brain segmentation at the invertebrate-to-vertebrate transition. Evol Dev 2005; 7:223-233.

50. Holland LZ. Non-neural ectoderm is really neural: evolution of developmental patterning mechanisms in the non-neural ectoderm of chordates and the problem of sensory cell homologies. J Exp Zoolog B Mol Dev Evol 2005; 304:304-323.

51. Benito-Gutierrez E, Nake C, Llovera M, Comella JX, GarciaFernandez J. The single AmphiTrk receptor highlights increased complexity of neurotrophin signalling in vertebrates and suggests an early role in developing sensory neuroepidermal cells. Development 2005; 132:2191-2202.

52. Panopoulou GD, Clark MD, Holland LZ, Lehrach H, Holland ND. AmphiBMP2/4, an amphioxus bone morphogenetic protein closely related to Drosophila decapentaplegic and vertebrate BMP2 and BMP4: insights into evolution of dorsoventral axis specification. Dev Dyn 1998; 213:130-139.

53. Schubert M, Holland LZ, Holland ND. Characterization of an amphioxus wnt gene, AmphiWnt11, with possible roles in myogenesis and tail outgrowth. Genesis 2000; 27:1-5.

54. Yu JK, Holland ND, Holland LZ. AmphiFoxQ2, a novel winged helix/forkhead gene, exclusively marks the anterior end of the amphioxus embryo. Dev Genes Evol 2003; 213:102-105.

55. Holland ND, Zhang SC, Clark M, Panopoulou G, Lehrach H, Holland LZ. Sequence and developmental expression of AmphiTob, an amphioxus homolog of vertebrate Tob in the PC3/BTG1/Tob family of tumor suppressor genes. Dev Dyn 1997; 210:11-18.

56. Lacalli TC. Sensory systems in amphioxus: a window on the ancestral chordate condition. Brain Behav Evol 2004; 64:148-162.

57. Holland LZ, Holland ND. Evolution of neural crest and placodes: amphioxus as a model for the ancestral vertebrate? J Anat 2001; 199:85-98.

58. Minguillon C, Ferrier DE, Cebrian C, Garcia-Fernandez J. Gene duplications in the prototypical cephalochordate amphioxus. Gene 2002; 287:121-128.

59. Meulemans D, Bronner-Fraser M. Amphioxus and lamprey AP2 genes: implications for neural crest evolution and migration patterns. Development 2002; 129:4953-4962.

60. Meulemans D, Bronner-Fraser M. Gene-regulatory interactions in neural crest evolution and development. Dev Cell 2004; 7:291299.

Tables

Table 1. Summary of gene expression in the nervous system and non-neural ectoderm

\begin{tabular}{|c|c|c|c|c|}
\hline Gene & Neural ectoderm expression & $\begin{array}{c}\text { Non-neural ectoderm } \\
\text { expression }\end{array}$ & Orientative functions in vertebrates & References \\
\hline AmHNF-3-1 & $\begin{array}{l}\text { Ventral midline of the neural } \\
\text { tube (Floor plate) }\end{array}$ & Negative & $\begin{array}{l}\text { Neural induction and notochord } \\
\text { specification (organiser functions) }\end{array}$ & [17] \\
\hline AmHNF-3-2 & Negative & Negative & & \\
\hline AmphiBMP2/4 & Negative & $\begin{array}{c}\text { Anterodorsal patch of rostral } \\
\text { epidermis }\end{array}$ & Dorsoventral axis patterning & [52] \\
\hline AmphiBrn1/2/4 & $\begin{array}{l}\text { Neural plate (excluding } \\
\text { ventral midline) and cerebral } \\
\text { vesicle }\end{array}$ & Negative & Neurogenesis & [25] \\
\hline AmphiCdx & Posterior neural tube & Posterior ectoderm & Axial patterning & [65] \\
\hline AmphiCoe & $\begin{array}{l}\text { Bilateral series of dorsal and } \\
\text { ventral cells within the neural } \\
\text { tube and posterior cerebral } \\
\text { vesicle }\end{array}$ & $\begin{array}{l}\text { Ventrolateral scattered } \\
\text { individual epidermal cells }\end{array}$ & Neuronal differentiation & [43] \\
\hline AmphiD1 & $\begin{array}{l}\text { Particular regions of the } \\
\text { cerebral vesicle }\end{array}$ & Negative & Neurotransmission & [33] \\
\hline AmphiDach & $\begin{array}{l}\text { Particular regions of the } \\
\text { cerebral vesicle and scattered } \\
\text { cells within the neural tube }\end{array}$ & Negative & $\begin{array}{c}\text { Central nervous system } \\
\text { development } \\
\text { Eye and limb development }\end{array}$ & [48] \\
\hline AmphiDll & $\begin{array}{l}\text { Anterior neural plate borders, } \\
\text { roof plate and ventrolateral } \\
\text { cells in the vicinity of the } \\
\text { pigment spot }\end{array}$ & $\begin{array}{l}\text { Spread all over the } \\
\text { epidermis }\end{array}$ & $\begin{array}{l}\text { Ectoderm regionalisation, } \\
\text { dorsoventral axis establishment and } \\
\text { forebrain specification }\end{array}$ & [32] \\
\hline
\end{tabular}

61. Jeffery WR, Strickler AG, Yamamoto Y. Migratory neural crestlike cells form body pigmentation in a urochordate embryo. Nature 2004; 431:696-699.

62. Holland ND, Holland LZ. Stage- and tissue-specific patterns of cell division in embryonic and larval tissues of amphioxus during normal development. Evol Dev 2006; 8:142-149.

63. Bayascas JR, Yuste VJ, Benito E, Garcia-Fernandez J, Comella JX. Isolation of AmphiCASP-3/7, an ancestral caspase from amphioxus (Branchiostoma floridae). Evolutionary considerations for vertebrate caspases. Cell Death Differ 2002;

64. Lowe CJ, Wu M, Salic A, Evans L, Lander E, Stange-Thomann N, Gruber CE, Gerhart J, Kirschner M. Anteroposterior patterning in hemichordates and the origins of the chordate nervous system. Cell 2003; 113:853-865.

65. Brooke NM, Garcia-Fernandez J, Holland PW. The ParaHox gene cluster is an evolutionary sister of the Hox gene cluster.

66. Holland LZ, Kene M, Williams NA, Holland ND. Sequence and embryonic expression of the amphioxus engrailed gene (AmphiEn): the metameric pattern of transcription resembles that of its segment-polarity homolog in Drosophila. Development 1997; 124:1723-1732.

67. Kozmik Z, Holland ND, Kalousova A, Paces J, Schubert M, Holland LZ. Characterization of an amphioxus paired box gene, AmphiPax2/5/8: developmental expression patterns in optic support cells, nephridium, thyroid-like structures and pharyngeal gill slits, but not in the midbrain-hindbrain boundary region. Development 1999; 126:1295-1304.

68. Schubert M, Holland LZ, Holland ND. Characterization of two amphioxus Wnt genes (AmphiWnt4 and AmphiWnt7b) with early expression in the developing central nervous system. Dev Dyn 2000; 217:205-215.

69. Schubert M, Holland LZ, Panopoulou GD, Lehrach H, Holland ND. Characterization of amphioxus AmphiWnt8: insights into the evolution of patterning of the embryonic dorsoventral axis. Evol Dev 2000; 2:85-92.

70. Wang Y, Zhang PJ, Yasui K, Saiga H. Expression of Bblhx3, a LIM-homeobox gene, in the development of amphioxus Branchiostoma belcheri tsingtauense. Mech Dev 2002; 117:315319.

71. Sedlacek Z, Shimeld SM, Munstermann E, Poustka A. The amphioxus rab GDP-dissociation inhibitor (GDI) gene is neuralspecific: implications for the evolution of chordate rab GDI genes. Mol Biol Evol 1999; 16:1231-1237. 9:1078-1089. Nature 1998; 392:920-922. 


\begin{tabular}{|c|c|c|c|c|}
\hline Gene & Neural ectoderm expression & $\begin{array}{l}\text { Non-neural ectoderm } \\
\text { expression }\end{array}$ & Orientative functions in vertebrates & References \\
\hline AmphiDRAL & Negative & $\begin{array}{l}\text { Homogeneously expressed } \\
\text { all over the epidermis }\end{array}$ & Differentiation & [13] \\
\hline AmphiElav & $\begin{array}{l}\text { Bilateral series of dorsal and } \\
\text { ventral cells within the neural } \\
\text { tube and posterior the } \\
\text { cerebral vesicle }\end{array}$ & $\begin{array}{l}\text { Ventrolateral scattered } \\
\text { individual epidermal cells }\end{array}$ & $\begin{array}{l}\text { Neurogenesis and neuronal } \\
\text { differentiation }\end{array}$ & {$[42][44]$} \\
\hline AmphiEn & $\begin{array}{c}\text { Posterior cerebral vesicle and } \\
\text { two clusters of cells within } \\
\text { the neural tube at the trunk } \\
\text { level }\end{array}$ & $\begin{array}{l}\text { Ventrolateral band of } \\
\text { scattered epidermal cells at } \\
\text { the level of the second } \\
\text { somite }\end{array}$ & $\begin{array}{l}\text { Rostrocaudal segmentation and } \\
\text { neurogenesis } \\
\text { Specification and maintenance of } \\
\text { boundaries }\end{array}$ & {$[66]$} \\
\hline AmphiERR & $\begin{array}{l}\text { Bilateral series of ventral cells } \\
\text { within the neural tube and } \\
\text { the presumptive frontal eye }\end{array}$ & $\begin{array}{c}\text { Ventrolateral scattered } \\
\text { individual epidermal cells at } \\
\text { the trunk level }\end{array}$ & Neuronal differentiation & [49] \\
\hline AmphiEvxA & $\begin{array}{l}\text { Two bilateral clusters of cells } \\
\text { within the neural tube at the } \\
\text { trunk level }\end{array}$ & Posterior ectoderm & $\begin{array}{l}\text { Gastrulation, neurogenesis, } \\
\text { appendage development and tailbud } \\
\text { formation }\end{array}$ & [23] [58] \\
\hline AmphiEvxB & Negative & $\begin{array}{l}\text { Homogeneously expressed } \\
\text { all over the epidermis }\end{array}$ & & \\
\hline AmphiFoxB & $\begin{array}{l}\text { Iterative series of cells in the } \\
\text { neural plate and } \\
\text { two patches of cells within the } \\
\text { cerebral vesicle }\end{array}$ & Negative & Neural segmentation & {$[34]$} \\
\hline AmphiFoxD & $\begin{array}{l}\text { Anterior neural plate and } \\
\text { ventral cerebral vesicle }\end{array}$ & Negative & Neural crest development & [19] \\
\hline AmphiFoxQ2 & Negative & Rostral ectoderm & & [54] \\
\hline AmphiFringe & $\begin{array}{l}\text { Iterative series of cells in the } \\
\text { anterior neural plate and in } \\
\text { the cerebral vesicle }\end{array}$ & Negative & $\begin{array}{l}\text { Specification and maintenance of } \\
\text { boundaries }\end{array}$ & {$[47]$} \\
\hline AmphiF-spondin & $\begin{array}{c}\text { Cerebral vesicle and neural } \\
\text { tube (most of the central } \\
\text { nervous system) }\end{array}$ & Negative & Neural specific extracelular matrix & [37] \\
\hline AmphiGli & Neural plate & Unknown & Motor neuron induction & {$[24]$} \\
\hline AmphiGsx & Cerebral vesicle & Negative & Axial patterning & {$[65]$} \\
\hline AmphiHairyA & Posterior neural tube & Negative & Neurogenesis and somitogenesis & [27] \\
\hline AmphiHairyB & $\begin{array}{l}\text { Bilateral gapped expression in } \\
\text { the neural tube }\end{array}$ & Negative & & \\
\hline AmphiHairyC & $\begin{array}{l}\text { Bilateral gapped expression in } \\
\text { the neural tube }\end{array}$ & Negative & & \\
\hline AmphiHairyD & $\begin{array}{l}\text { Bilateral gapped expression in } \\
\text { the neural tube }\end{array}$ & Negative & & \\
\hline AmphiHh & $\begin{array}{l}\text { Ventral midline of the neural } \\
\text { tube (Floor plate) }\end{array}$ & Negative & Axial patterning & [38] \\
\hline AmphiHox1 & $\begin{array}{l}\text { Segmented expression in the } \\
\text { neural tube (S2-S4) }\end{array}$ & $\begin{array}{c}\text { Ventrolateral scattered } \\
\text { individual epidermal cells at } \\
\text { the trunk level }\end{array}$ & Axial patterning & {$[4][35]$} \\
\hline AmphiHox3 & $\begin{array}{l}\text { Segmented expression in the } \\
\text { neural tube (S4-S8) }\end{array}$ & $\begin{array}{c}\text { Ventrolateral scattered } \\
\text { individual epidermal cells at } \\
\text { the trunk-caudal level }\end{array}$ & & \\
\hline AmphiHox4 & $\begin{array}{l}\text { Segmented expression in the } \\
\text { neural tube (S6-S8) }\end{array}$ & $\begin{array}{l}\text { Ventrolateral scattered } \\
\text { individual epidermal cells at } \\
\text { the caudal level }\end{array}$ & & \\
\hline AmphiKrox & $\begin{array}{l}\text { Bilateral iterative series of } \\
\text { cells in the neural plate and } \\
\text { cerebral vesicle }\end{array}$ & Negative & $\begin{array}{l}\text { Specification and maintenance of } \\
\text { segmental identity }\end{array}$ & [39] [41] \\
\hline AmphiMnx & $\begin{array}{l}\text { Bilateral iterative series of } \\
\text { cells in the neural plate }\end{array}$ & Negative & Motor neuron differentiation & {$[40]$} \\
\hline AmphiMsx & $\begin{array}{l}\text { Dorsolateral series of cells in } \\
\text { the neural tube }\end{array}$ & $\begin{array}{l}\text { Bilateral patches of rostral } \\
\text { epidermal cells }\end{array}$ & $\begin{array}{l}\text { Nervous system development } \\
\text { Neural crest and placodes } \\
\text { development }\end{array}$ & [21] \\
\hline AmphiNetrin & $\begin{array}{l}\text { Ventral midline of the neural } \\
\text { tube (Floor plate) }\end{array}$ & Negative & Axonal path finding & [36] \\
\hline AmphiNeurogenin & $\begin{array}{l}\text { Neural plate (excluding } \\
\text { ventral midline) and dorsal } \\
\text { neural tube later in } \\
\text { development }\end{array}$ & $\begin{array}{l}\text { Scattered cells of the rostral } \\
\text { epidermis }\end{array}$ & $\begin{array}{l}\text { Neural specification and } \\
\text { differentiation }\end{array}$ & [12] \\
\hline AmphiNk2-1 & $\begin{array}{l}\text { Ventral midline of neural tube } \\
\text { (Floor plate) and ventral } \\
\text { cerebral vesicle }\end{array}$ & Negative & $\begin{array}{l}\text { Development of the central nervous } \\
\text { system and thyroid gland }\end{array}$ & [46] \\
\hline AmphiNk2-2 & $\begin{array}{l}\text { Ventrolateral cells within the } \\
\text { cerebral vesicle }\end{array}$ & Negative & Nervous system regionalisation & [45] \\
\hline AmphiNotch & $\begin{array}{c}\text { Posterior and anterior neural } \\
\text { plate } \\
\text { Dorsal cells of the cerebral } \\
\text { vesicle }\end{array}$ & Negative & $\begin{array}{l}\text { Cell fate decision in the } \\
\text { neuroectoderm and formation of } \\
\text { boundaries }\end{array}$ & [10] \\
\hline AmphiOtx & Cerebral vesicle & $\begin{array}{l}\text { Scattered cells of the } \\
\text { rostrodorsal epidermis }\end{array}$ & Anterior head formation & [16] \\
\hline AmphiPax2/5/8 & $\begin{array}{l}\text { Neural tube and anterodorsal } \\
\text { cerebral vesicle }\end{array}$ & Negative & $\begin{array}{l}\text { Midbrain-hindbrain boundary } \\
\text { formation }\end{array}$ & [67] \\
\hline AmphiPax3/7 & $\begin{array}{l}\text { Anterior neural plate and } \\
\text { dorsal third of cerebral vesicle }\end{array}$ & Dorsal ectoderm & $\begin{array}{l}\text { Dorsoventral regionalisation of the } \\
\text { central nervous system, neural crest } \\
\text { and placodes development, and }\end{array}$ & [26] \\
\hline
\end{tabular}




\begin{tabular}{|c|c|c|c|c|}
\hline Gene & Neural ectoderm expression & $\begin{array}{c}\text { Non-neural ectoderm } \\
\text { expression }\end{array}$ & Orientative functions in vertebrates & References \\
\hline & & & myogenesis & \\
\hline AmphiPax6 & $\begin{array}{l}\text { Anterior neural tube and } \\
\text { cerebral vesicle }\end{array}$ & Anterior epidermis & $\begin{array}{l}\text { Eye development and cell type } \\
\text { specification }\end{array}$ & [20] \\
\hline AmphiSim & Posterior cerebral vesicle & Negative & Neural segmentation & [34] \\
\hline AmphiSox $1 / 2 / 3$ & Dorsal neural tube & Negative & $\begin{array}{c}\text { Neural specification and } \\
\text { differentiation }\end{array}$ & [12] \\
\hline AmphiTH & $\begin{array}{l}\text { Particular regions of the } \\
\text { cerebral vesicle }\end{array}$ & Negative & Neurotransmission & [33] \\
\hline AmphiTob & $\begin{array}{l}\text { Scattered cells along the } \\
\text { neural tube and cerebral } \\
\text { vesicle }\end{array}$ & Anterior epidermis & Proliferation arrest & {$[55]$} \\
\hline AmphiTrk & $\begin{array}{l}\text { Ventral and dorsal neural } \\
\text { tube (adults) }\end{array}$ & $\begin{array}{c}\text { Ventrolateral scattered } \\
\text { individual epidermal cells }\end{array}$ & $\begin{array}{c}\text { Neuronal survival and } \\
\text { differentiation }\end{array}$ & [51] \\
\hline AmphiVent & Neural plate borders & Negative & Mesoderm patterning & [14] \\
\hline AmphiWnt11 & Presumptive neuroectoderm & $\begin{array}{l}\text { Dorsal, anteroventral and } \\
\text { posterior ectoderm }\end{array}$ & Axial patterning & [53] \\
\hline AmphiWnt3 & $\begin{array}{l}\text { Neural plate borders and } \\
\text { cerebral vesicle }\end{array}$ & Posterior ectoderm & & [9] \\
\hline AmphiWnt4 & $\begin{array}{l}\text { Neural tube and posterior } \\
\text { cerebral vesicle }\end{array}$ & Negative & & {$[68]$} \\
\hline AmphiWnt5 & Ventral cerebral vesicle & Negative & & [9] \\
\hline AmphiWnt6 & $\begin{array}{l}\text { Neural plate borders and } \\
\text { posterior neural tube }\end{array}$ & Negative & & \\
\hline AmphiWnt7b & Neural tube & Negative & & [68] \\
\hline AmphiWnt8 & $\begin{array}{l}\text { Patch of cells within the } \\
\text { ventral cerebral vesicle }\end{array}$ & Negative & & \\
\hline AmphiXlox & $\begin{array}{l}\text { Transient cluster of cells in } \\
\text { the neural tube at the level of } \\
\text { somite } 5 \text { (pigment spot) }\end{array}$ & Negative & Axial patterning & [65] \\
\hline AmphiZic & $\begin{array}{c}\text { Neural tube and cerebral } \\
\text { vesicle }\end{array}$ & Negative & Neural crest induction & {$[24]$} \\
\hline AP-2 & Cerebral vesicle & $\begin{array}{l}\text { Spread all over the } \\
\text { epidermis }\end{array}$ & Neural crest development & [59] \\
\hline Bblhx3 & $\begin{array}{l}\text { Bilateral iterative series of } \\
\text { cells within the neural tube }\end{array}$ & Negative & $\begin{array}{c}\text { Axial patterning and neuronal } \\
\text { differentiation }\end{array}$ & [70] \\
\hline BF-1 & Anteroventral cerebral vesicle & Negative & Telencephalon development & [31] \\
\hline Id & Anterior neuroectoderm & Negative & Neural crest development & [28] \\
\hline Islet & $\begin{array}{l}\text { Bilateral iterative series of } \\
\text { cells within the neural tube }\end{array}$ & $\begin{array}{c}\text { Ventrolateral band of } \\
\text { scattered epidermal cells at } \\
\text { the trunk level and rostral } \\
\text { epidermis }\end{array}$ & $\begin{array}{c}\text { Neuronal patterning and } \\
\text { differentiation }\end{array}$ & [4] [22] [41] \\
\hline rab GDI & $\begin{array}{l}\text { Anterior neural tube and } \\
\text { cerebral vesicle }\end{array}$ & Negative & $\begin{array}{l}\text { Regulation of vesicle-mediated } \\
\text { cellular transport }\end{array}$ & [71] \\
\hline Shox & $\begin{array}{l}\text { Bilateral iterative series of } \\
\text { cells within the neural tube }\end{array}$ & Negative & $\begin{array}{l}\text { Growth control and neural } \\
\text { specification }\end{array}$ & [41] \\
\hline Snail & Ventrolateral neural tube & Dorsal ectoderm & Neural crest development & [30] \\
\hline
\end{tabular}

